Engineering, Technology and Techniques

Vol.60: e17160260, January-December 2017 http://dx.doi.org/10.1590/1678-4324-2017160260 ISSN 1678-4324 Online Edition

\title{
Enhancement of biohydrogen production from starch processing wastewater and further inside its ecosystem disclosed by 16 S rDNA sequencing and FISH
}

\author{
Chonlapin Sutthipattanasomboon ${ }^{1}$ and Jaruwan Wongthanate ${ }^{1^{*}}$ \\ ${ }^{1}$ Mahidol University - Faculty of Environment and Resource Studies, Nakhon Pathom, Thailand.
}

\begin{abstract}
Biohydrogen production from starch processing wastewater in this study resulted the highest yield of $61.75 \mathrm{~mL} \mathrm{H}_{2} / \mathrm{g}$ COD at initial pH 7.0, thermophilic temperature, and iron concentration $800 \mathrm{mg} F \mathrm{Fe}$. The yield was 2-folded higher than the operation at mesophilic temperature or without iron addition. Cell immobilization by addition of biomaterials (BM) could improve the hydrogen yield by 2-folded comparing to the non-addition. BM from plants (loofa sponge) was found producing higher yield than that from animals (silk cocoon), and optimal concentration of $B M$ was $5 \%(V / V)$. Furthermore, it was revealed further inside its ecosystem using SEM, 16S rDNA sequencing and FISH. There was found rod-shaped microorganisms of Bacillus cereus, which reported as efficient starch-utilizing hydrogen producers, was dominant in the system with population of $47 \%$ of all specie identified.
\end{abstract}

Key words: biohydrogen production, starch processing wastewater, biological supporting materials, Bacillus cereus

\footnotetext{
*Author for correspondence: jaruwan.won@mahidol.ac.th
} 


\section{INTRODUCTION}

Due to high demand of energy while decreasing of common fuels such as coal and oil, alternative fuel became an interesting idea. Hydrogen is one of the promising fuels because of zero-emission of greenhouse gases. It can be produced from cheap and abundant sources like organic waste or wastewater by means of biological fermentation, photo and/or dark fermentation, which only hydrogen fuel production, but this process also helps wastewater treatment. Dark fermentation has advantages over photo fermentation since it allows smaller operational space and wider usage of substrates and microbial species, even mixed culture. Substrates for biological fermentation were reported using carbohydrate-rich waste/ wastewater such as food waste, starch waste/ wastewater ${ }^{[1]}$.

There are many parameters affect hydrogen yield. However, the important ones are initial $\mathrm{pH}$ and operational temperature, since it directly influence bacterial growth, metabolic pathways and dominant species ${ }^{[2]}$. Moreover, there were reports about using iron and cell immobilization to increase hydrogen yield. Iron could improve hydrogenase enzyme activity, which involve in hydrogen formation, as a component on active site of the enzyme ${ }^{[3]}$. Immobilization of bacteria on supporting materials helps improve hydrogen productivity by acclimatization of microbes, decreasing lag phase of bacterial cultivation ${ }^{[4]}$, and increasing density of consortia ${ }^{[5]}$. There were many reports of using synthetic materials but fewer publications studied about biological supporting materials (BM).

Consequently, this research was focused on the identification of optimal environment for anaerobic dark fermentation of starch-processing wastewater (initial $\mathrm{pH}$, temperature, and iron concentration) and comparison of the enhancement after using biological supporting materials both from animals and plants as well as identify microbial morphology and population of dominant hydrogen producers.

\section{MATERIALS AND METHODS}

\section{Preparation of Feedstock and Biological Supporting Materials}

Starch processing wastewater was from starch producing factory by a water sampler (grab sampling method) where was located in Nakhonpathom province, Thailand. Starch processing wastewater was used as substrate for fermentative hydrogen production. The physical and chemical characteristics of starch processing wastewater were $\mathrm{pH}$ 5, COD 2,000 mg/L, TKN $308 \mathrm{mg} / \mathrm{L}$, TS 36,460 mg/L and Total iron $0.20 \mathrm{mg} / \mathrm{L}^{[6]}$. Anaerobic sludge was taken from the Bio-fertilizer plant, Nonthaburi province, Thailand.

Studied biological supporting materials (BM) were loofa sponge (LS) from plants and silk cocoon (SC) from animals (Bombyx mori). They were tested for acid tolerance ( $\mathrm{pH} 4.0)$ and cell immobilization. The amount of immobilized biomass per gram of BM was determined by measuring the difference in dry weights of BM before and after the immobilization and divide by gram of dry weight of added BM. Moreover, they were minimized into size of $0.5-1.0 \mathrm{~cm}$ and shaped into rectangular, parallelepiped or triangular. Characteristics of LS and SC are displayed in Table 1.

Table 1 Physical characterization and cell immobilization ability of biological supporting materials (BM)

\begin{tabular}{ccccc}
\hline BM & Acid tolerance & $\begin{array}{c}\text { Average density } \\
\left(\mathrm{g} / \mathrm{cm}^{3}\right)\end{array}$ & $\begin{array}{c}\text { Surface area } \\
\left(\mathrm{m}^{2} / \mathrm{g}\right)\end{array}$ & $\begin{array}{c}\text { Cell immobilization } \\
(\mathrm{mg} / \mathrm{g} \mathrm{BM})\end{array}$ \\
\hline Loofa sponge & Yes & 0.045 & 174.50 & 0.080 \\
Silk cocoon & Yes & 0.190 & 326.40 & 0.031 \\
\hline
\end{tabular}


Hydrogen fermentation from starch wastewater

\section{EXPERIMENTAL SETUP}

Dark fermentation was done in laboratory bottle covered with black sheet and connected to air bag with 3-way valve for collecting the gas product. Each batch comprised $10 \mathrm{~mL}$ of seed sludge, $140 \mathrm{~mL}$ of the wastewater, and nutrient solution, till working volume was $180 \mathrm{~mL}$ in total. Seed sludge was heat-treated at $90^{\circ} \mathrm{C}$ for $10 \mathrm{~min}$ before used to inhibit hydrogen-consuming bacteria. One liter of nutrient solution composed of $10 \mathrm{~g}$ D-Glucose, $5.240 \mathrm{~g} \mathrm{NH}_{4} \mathrm{HCO}_{3}, 6.720 \mathrm{~g}$ of $\mathrm{NaHCO}_{3}$, $0.125 \mathrm{~g} \mathrm{~K}_{2} \mathrm{HPO}_{4}, 0.100 \mathrm{~g} \mathrm{MgCl}_{2} \bullet \mathrm{H}_{2} \mathrm{O}, 15 \mathrm{mg} \mathrm{MnSO}{ }_{4} \bullet 6 \mathrm{H}_{2} \mathrm{O}{ }^{[7]}$. The solution was purged with nitrogen gas to create anaerobic condition.

The optimal fermentation condition was studied from variation of initial $\mathrm{pH}$ (4.0, 5.0, 6.0, 7.0, and 8.0) adjusted by $6.0 \mathrm{M} \mathrm{H}_{2} \mathrm{SO}_{4}$ and $1.0 \mathrm{M} \mathrm{KOH}$, temperature (mesophilic, $35 \pm 2^{\circ} \mathrm{C}$ and thermophlic, $55 \pm 2^{\circ} \mathrm{C}$ ) controlled using water bath, initial iron concentration $(200,400,600,800,1000 \mathrm{mg} \mathrm{Fe} / \mathrm{L})$ in form of Iron (II) sulphate $\left(\mathrm{FeSO}_{4}\right)$, and BM concentration $(0,5,10,15$, and $20 \%(\mathrm{~V} / \mathrm{V}))$. BM which obtained the maximum hydrogen yield in each group (plant and animal) was selected to be a representative of its group and to compare with another group.

\section{Analytical Method}

Composition of produced biogas $\left(\mathrm{H}_{2}, \mathrm{CO}_{2}\right.$, and $\left.\mathrm{CH}_{4}\right)$ were daily monitored and analyzed by using gas chromatography (GC) (Varian STAR 3400, US) equipped with thermal conductivity detector. Chromatography column made of stainless-steel was packed (Alltech Molesieve 5A 80/100 10'x 1/8"). Carrier gases were Argon (Ar) for hydrogen and methane analysis, and helium for $\mathrm{CO}_{2}$ analysis ${ }^{[8]}$. The temperatures of injector, detector and column were stably operated at $80^{\circ} \mathrm{C}, 90^{\circ} \mathrm{C}$ and $50^{\circ} \mathrm{C}$ respectively. Gas volume was daily measured using glass syringe ${ }^{[9]}$.

$\mathrm{pH}$ was daily monitored using $\mathrm{pH}$ strips and concentration of volatile fatty acid or VFA (acetic, propionic and butyric acids) was observed before and after the fermentation. The products were sampled for $5 \mathrm{~mL}$ using syringe, and centrifuged at $10,000 \mathrm{rpm}$ for 2 minutes ( $\mathrm{min}$ ) to separate solid remaining in the sampled solution. Then, the concentration of liquid product was measured by a gas chromatography flame ionization detector (GC-FID), equiped with TG-WAXMS A column. The carrier gas was helium with a flow rate at $3 \mathrm{~mL} / \mathrm{min}$. The operating temperature of injector and detector were $230^{\circ} \mathrm{C}$ and $250^{\circ} \mathrm{C}$, respectively. The temperature of oven was $50^{\circ} \mathrm{C}$ for 2 minutes then increasing to $230^{\circ} \mathrm{C}$ by rate of $50^{\circ} \mathrm{C}$ per minute. After that the temperature was controlled to stay at $230^{\circ} \mathrm{C}$ for 3 minutes. Chemical oxygen demand (COD) of wastewater was investigated after the fermentation according to identify performance in terms of wastewater treatment ${ }^{[6]}$.

Hydrogen gas production was calculated from headspace measurements and the total volume of biogas produced for each time interval according from equation presented [10].

$\mathrm{V}_{\mathrm{H}, \mathrm{i}}=\mathrm{V}_{\mathrm{H}, \mathrm{i}-1}+\mathrm{C}_{\mathrm{H}, \mathrm{i}}\left(\mathrm{V}_{\mathrm{G}, \mathrm{i}}-\mathrm{V}_{\mathrm{G}, \mathrm{i}-1}\right)+\mathrm{V}_{\mathrm{H}}\left(\mathrm{C}_{\mathrm{H}, \mathrm{i}} \mathrm{C}_{\mathrm{H}, \mathrm{i}-1}\right)$

While $\mathrm{V}_{\mathrm{H}, \mathrm{i}}$ and $\mathrm{V}_{\mathrm{H}, \mathrm{i}-1}$ are cumulative hydrogen gas volumes at the current (i) and previous (i-1) time interval, respectively, $\mathrm{V}_{\mathrm{G}, \mathrm{i}}$ and $\mathrm{V}_{\mathrm{G}, \mathrm{i}-1}$ are the total biogas volumes in the current and previous time intervals, $\mathrm{C}_{\mathrm{H}, \mathrm{i}}$ and $\mathrm{C}_{\mathrm{H}, \mathrm{i}-1}$ are the fraction of hydrogen gas in the headspace of the bottle measured by means of gas chromatography in the current and next time intervals, and $\mathrm{VH}$ is the total volume of headspace in the reactor. 
Cumulative hydrogen gas volume was calculated by using modified Gompertz equation ${ }^{[10]}$.

$H(t)=H_{\max } \exp \left[-\exp \left\{\frac{\mathrm{R}_{\max } \mathrm{e}}{\mathrm{H}_{\max }}(\lambda-t)+1\right\}\right]$

While $H(t)$ is cumulative hydrogen production $(\mathrm{mL}) . \mathrm{H}_{\max }$ and $\mathrm{R}_{\max }$ are maximum volume of hydrogen production potential $(\mathrm{mL})$ and maximum hydrogen rate $(\mathrm{mL} / \mathrm{h})$, respectively. $\lambda$ is lag phase (h), t stands for time (h), e equals to 2.71828 .

Following statistical tools were used mean (X), standard deviation (SD) and percentage to explain (a) difference of the cumulative hydrogen production ( $\mathrm{ml}$ ) by time (day) at various $\mathrm{pH}$, temperature and iron concentration (b) difference of the VFAs $(\mathrm{mg} / \mathrm{L})$ before and after the fermentation at various mentioned conditions and (c) microbial population between BM with produced highest and lowest hydrogen production. Microsoft Excel 2010 supported for statistic calculation.

\section{Cell Morphology and Bioinformatics Analysis}

The cell morphology and microbial community was determined using scanning electron microscope or SEM ${ }^{[11]}$, $16 \mathrm{~S}$ rRNA fluorescence in situ hybridization or FISH ${ }^{[12]}$, and 16S rDNA sequence analysis. The specimens were collected from the day that obtained highest production of hydrogen and prepared as following.

SEM: The BMs were pre-fixed with $2.5 \%$ gluteraldehyde for 24 hours and washed with $0.1 \mathrm{M}$ phosphate buffer ( $\mathrm{pH}$ 7.2-7.4) 3 times for 10 minutes each. After that, the fixed samples were post-fixed with 1-2\% osmium tetraoxide (OsO4) for 1-2 hours, and washed with distilled water 3 times for 10-30 minutes each. Then they were dehydrated with series of ethanol $20,40,60,80,95,95,95 \%$, respectively, for $10-30$ minutes each, and dried with critical point dryer for 30 minutes. The samples were coated with gold and monitored in SEM (JEOL, JSM-5600LV)

16S rDNA amplification and sequence analysis: 16S rDNA analysis was studied using next generation sequencing (NGS). 16S rDNA was extracted as follow. Microorganisms on BMs were collected by submerging BMs in 1x Phosphate buffer saline (PBS) and spinning using vortex to detach the cell on them. The detached cells were fixed with $4 \%$ formaldehyde in 1X PBS for 24 hours then washed 3 times with 1x PBS for 15 minutes each. After washing, 1:1 PBS:ethanol solution was added and the samples were stored at $-20{ }^{\circ} \mathrm{C}$ for next usage.

The detached cells were extracted for their DNA by following a PCR cleanup protocol in GenepHlow Gel/PCR Kit (Geneaid, Taiwan). The extracted DNA sample was processed and analyzed at BGI Co., Ltd (Hongkong, China). For amplification, the extracted DNA samples were amplified the 16s rRNA gene by Polymerase Chain Reaction (PCR) with the primers 341F (5'-CCTACGGGNGGCWGCAG-3') and 802R (5'-TACNVGGGTATCTAATCC-3') ${ }^{[13]}$. The jagged ends of DNA fragment would be converted into blunt ends by using T4 DNA polymerase, Klenow Fragment and T4 Polynucleotide Kinase. Then add an 'A' base to each 3' end to make it easier to add adapters. After all that, too short fragments would be removed by Ampure beads.

Then paired-end reads with overlap were merged to tags, and the tags were clustered to Operational Taxonomic Unit (OUT) at $97 \%$ sequence similarity by scripts of software USEARCH (v7.0.1090) ${ }^{[14]}$. Taxonomic ranks were assigned to OTU representative sequence using Ribosomal Database Project (RDP) Na,e Bayesian Classifier v.2.2. The RDP was examined with a corpus of 23,095 rRNA sequences as provided by the National Center for Biotechnology Information (NCBI) ${ }^{[15]}$. At last, alpha diversity, beta diversity and the different species screening were analyzed 
Hydrogen fermentation from starch wastewater

based on OTU and taxonomic ranks. Paired-end reads were generated with Illumina HiSeq/MiSeq platform, and then the reads with sequencing adapters, $\mathrm{N}$ base, poly base, low quality etc were filtered out with default parameters. Average reads length was 460 base pairs.

FISH: The detached cells $(5 \mu \mathrm{L})$ were spotted on gelatin-coated fourteen-field glass slides and air dried at $37^{\circ} \mathrm{C}$ for $10 \mathrm{~min}$. Then they were dehydrated with 50,80 , and 95\% ethanol, respectively, for 3 minutes each, and air dried at room temperature. The probe pB196 (5'- CGG AAG ATT CCC TAC TGC -3') fluorescently labelled with hydrophilic sulfoindocyanine dye CY3 was used to target Firmicute phylum ${ }^{[16]}$. $50 \mu \mathrm{L}$ of reaction buffer was added on each sample spot. The buffer contained the probe and hybridization buffer at ratio 1:9. The hybridization buffer consisted of 0.9 $\mathrm{M} \mathrm{NaCl}, 0.01 \%$ SDS, and $20 \mathrm{mM}$ Tris-Hcl (pH 7.2). A process was operated in a water-saturated equilibration chamber at $46^{\circ} \mathrm{C}$ for 60 minutes then washed with a washing buffer at $48^{\circ} \mathrm{C}$ for 60 minutes. The washing buffer contained $0.9 \mathrm{M} \mathrm{NaCl}$, $0.01 \%$ SDS, and $20 \mathrm{mM}$ Tris-Hcl (pH 7.2), and was removed by rinsing with distilled water. The cells were counter-stained with $300 \mathrm{nM}$ DAPI for $50 \mu \mathrm{L}$ on each sample spot and leaved in humid chamber for 15 minutes. Washed a trace of the stain with distilled water and protected a de-colorization with anti-fade solution on each sample spot, then covered with a cover slide. Fluorescence image was detected with a confocal laser scanning microscope (Olympus, FLUOVIEW FV10i, US). For counting of bacteria, at least 4 slides for each sample, and at least 10 fields were counted for each slide. The average number of bacteria was taken.

\section{RESULTS AND DISCUSSION}

\section{Optimal temperature and initial $\mathrm{pH}$}

Hydrogen production and VFA concentrations in thermophilic temperature was found 2-folded higher than mesophilic temperature (Table 2). This may be a result of lower solubility of hydrogen gas when increasing of temperature ${ }^{[17]}$. Re-oxidation of reduced ferredoxin $(\mathrm{Fd})$, which generating hydrogen, by microbes was less preferable when higher concentration of dissolved hydrogen. Moreover, thermophilic temperature could improve degradation of substrate ${ }^{[18]}$.

Highest hydrogen generation was obtained at initial $\mathrm{pH} 7.0-8.0$, so neutral and slightly basic conditions were more preferable for fermentative hydrogen production in this study. Although, acetic acid (HAc) and butyric acid (HBu) was produced lower than the acidic condition, no detection of propionic acid (HPr) observed. HPr production process may consume hydrogen $(\mathrm{Eq} 1)^{[19]}$. Under neutral or slightly basic initial $\mathrm{pH}$ condition, the possible hydrogen consumption was lower that acidic condition hence higher hydrogen yield.

$\mathrm{C}_{6} \mathrm{H}_{12} \mathrm{O}_{6}+2 \mathrm{H}_{2} \rightarrow 2 \mathrm{CH}_{3} \mathrm{CH}_{2} \mathrm{COOH}+2 \mathrm{H}_{2} \mathrm{O}$

Moreover, the substrate was possibly converted to acetate without hydrogen generation such as Eq $2^{[20]}$. Not only acetate and butyrate pathways, but hydrogen may also be produced via other pathway, pyruvate-formate lyase (PFL), which generating formic acid $(\mathrm{HCOOH})$. $\mathrm{HCOOH}$ can convert to hydrogen and carbon dioxide (Eq 3 and 4) ${ }^{[21]}$. PFL pathway was favors neutral $\mathrm{pH}^{[22]}$.

$2 \mathrm{C}_{6} \mathrm{H}_{12} \mathrm{O}_{6} \rightarrow 3 \mathrm{CH}_{3} \mathrm{COOH}+2 \mathrm{CH}_{3} \mathrm{CHOHCOOH}$
Pyruvate $+\mathrm{CoA} \stackrel{\text { enzyme }}{\longrightarrow}$ Acetyl-CoA $+\mathrm{HCOOH}$ 


$$
2 \mathrm{HCOOH} \rightarrow 2 \mathrm{CO}_{2}+2 \mathrm{H}_{2}
$$

Table 2 Hydrogen production and VFA at various temperature and initial $\mathrm{pH}$

\begin{tabular}{llllll}
\hline \multirow{2}{*}{ Temperature } & \multirow{2}{*}{ Initial pH } & \multirow{2}{*}{$\begin{array}{l}\mathrm{H}_{2} \text { yield } \\
\left(\mathrm{mL} \mathrm{H}_{2} / \mathrm{g} \text { COD }\right)\end{array}$} & $\mathrm{HAc}^{\mathrm{a}}$ & $\mathrm{HPr}^{\mathrm{b}}$ & $\mathrm{HBu}^{\mathrm{c}}$ \\
\hline \multirow{4}{*}{ Mesophilic } & 4.0 & 13.42 & 6.53 & 2.79 & 0.00 \\
& 5.0 & 7.47 & 9.70 & 3.12 & 8.75 \\
& 6.0 & 9.52 & 19.6 & 1.65 & 11.35 \\
& 7.0 & 10.20 & 9.82 & 0.00 & 2.52 \\
& 8.0 & 13.84 & 6.60 & 0.00 & 1.17 \\
\hline \multirow{4}{*}{ Thermophilic } & 4.0 & 28.37 & 10.02 & 11.95 & 166.3 \\
& 5.0 & 30.19 & 16.63 & 19.69 & 91.8 \\
& 7.0 & 25.81 & 14.40 & 1.29 & 2.85 \\
& 8.0 & 37.59 & 7.28 & 0.00 & 1.00 \\
\hline
\end{tabular}

${ }^{\mathrm{a}} \mathrm{HAc}=$ acetic acid $;{ }^{\mathrm{b}} \mathrm{HPr}=$ propionic acid $;{ }^{\mathrm{c}} \mathrm{HBu}=$ butyric acid

In addition, it was also found that initial $\mathrm{pH}$ influenced to the beginning of hydrogen evolution time. Lag phase of 8 hours observed when initial $\mathrm{pH} 4.0-6.0$ and increased to 12 hours at initial $\mathrm{pH} 8.0$. Longer of lag time indicated that microbes need more time for adaptation into new environment ${ }^{[23]}$. Similar trend of increasing of lag phase from initial $\mathrm{pH}$ 6.0-8.0 was also observed in publications. Longer lag phase was increasing initial $\mathrm{pH}$ from 6.0 to 8.0 in anaerobic fermentation of starch and glucose ${ }^{[24]}$.

Nevertheless, optimal initial $\mathrm{pH}$ and operational temperature for biohydrogen production were reported various values. This may primarily result from dissimilarity of dominant microbial species in mixed culture and their sources ${ }^{[25]}$. Besides, the dominant species may possibly deviate under different operational environments.

Consequently, optimal initial $\mathrm{pH}$ and temperature that gave highest hydrogen yield (37.59 $\mathrm{mL} \mathrm{H}_{2} / \mathrm{g} \mathrm{COD)} \mathrm{in} \mathrm{this} \mathrm{work} \mathrm{were} \mathrm{pH} 7.0$ and thermophilic condition.

\section{Optimal iron concentration}

External addition of iron (Fe) obtained 2-3 folded higher of hydrogen yield than no iron addition (Table 3). Hydrogen yield increased when increasing initial iron concentration from 0 to $400 \mathrm{mg} \mathrm{Fe} / \mathrm{L}$, but slightly declined at $600 \mathrm{mg} \mathrm{Fe} / \mathrm{L}$. Maximum hydrogen yield of $61.76 \mathrm{~mL} / \mathrm{g}$ COD was found at initial iron concentration of $800 \mathrm{mg} \mathrm{Fe} / \mathrm{L}$, and dropped at $1000 \mathrm{mg} \mathrm{Fe} / \mathrm{L}$. Since iron is a key component in hydrogenase enzyme which responsible for hydrogen generation. Increasing of iron can enhance hydrogenase activity and hydrogen production. However, too much iron may be toxic for hydrogen-producing bacteria. Many publications also reported decreasing of hydrogen yield when using initial iron concentration more than $1000 \mathrm{mg} \mathrm{Fe} / \mathrm{L}^{[26]}$. Therefore, it may estimate that initial iron concentration of $1000 \mathrm{mg} \mathrm{Fe} / \mathrm{L}$ or more may be an iron toxicity limitation to hydrogen-producing microbes. Nevertheless, many publications informed different optimal initial iron concentration. Some works reported highest hydrogen production at initial iron concentration lower than $100 \mathrm{mg} \mathrm{Fe} / \mathrm{L}^{[27]}$, while some studies obtained maximum yield at initial iron concentration higher than $300 \mathrm{mg} / \mathrm{L}{ }^{[28]}$. Possible reasons may become from different substrate, source of microbes and/or dominant 
Hydrogen fermentation from starch wastewater

species, operated conditions. Accordingly, optimal iron concentration should be studied hinging on situation.

Table 3 Hydrogen and VFA production at various initial iron concentrations

\begin{tabular}{|c|c|c|c|c|}
\hline \multirow{2}{*}{$\begin{array}{l}\text { Initial Fe concentration } \\
(\mathrm{mg} / \mathrm{L})\end{array}$} & \multirow{2}{*}{$\begin{array}{l}\mathrm{H}_{2} \text { yield } \\
\left(\mathrm{mL} \mathrm{H}_{2} / \mathrm{g} \mathrm{COD}\right)\end{array}$} & \multicolumn{3}{|c|}{ VFA (ppm) } \\
\hline & & $\mathrm{HAc}^{\mathrm{a}}$ & $\mathrm{HPr}^{\mathrm{b}}$ & $\mathrm{HBu}^{\mathrm{c}}$ \\
\hline 0 & 26.87 & 5.40 & 0.00 & 0.52 \\
\hline 200 & 55.39 & 199.90 & 88.56 & 61.49 \\
\hline 400 & 58.06 & 100.19 & 37.73 & 25.93 \\
\hline 600 & 56.70 & 76.25 & 25.79 & 19.05 \\
\hline 800 & 61.76 & 51.95 & 14.22 & 9.34 \\
\hline 1000 & 50.17 & 33.42 & 7.74 & 5.12 \\
\hline
\end{tabular}

${ }^{\mathrm{a}} \mathrm{HAc}=$ acetic acid $;{ }^{\mathrm{b}} \mathrm{HPr}=$ propionic acid $;{ }^{\mathrm{c}} \mathrm{HBu}=$ butyric acid

In this study, optimal initial iron concentration that produced maximum hydrogen yield in present study was $800 \mathrm{mg} \mathrm{Fe} / \mathrm{L}$.

\section{Optimal BM concentration}

Addition of BM could enhance hydrogen yield. Maximum hydrogen production of 28.43 and $24.26 \mathrm{~mL} / \mathrm{gCOD}$ was observed at $5 \%(\mathrm{~V} / \mathrm{V})$ of LS and SC (Table 4), respectively. However, in SC, there was not much difference between the control and $5 \%(\mathrm{~V} / \mathrm{V}) \mathrm{BM}$ insertion. Furthermore, hydrogen yield decreased when increasing of BM concentration which may cause from restriction of flow area in the fermentation system ${ }^{[29]}$ and/or decreasing of void space for bacterial growth ${ }^{[30]}$. Thereby, optimal concentration of LS (plant) and SC (animal) for hydrogen production in this study were both $5 \%(\mathrm{~V} / \mathrm{V})$.

\section{Comparison of BM from plant and animal}

LS and SC at 5\% BM concentration were repeatedly compared for its hydrogen production enhancement. When adding loofa sponge hydrogen yield was $28.43 \mathrm{~mL} / \mathrm{g}$ COD, while hydrogen yield was $24.26 \mathrm{~mL} / \mathrm{g}$ COD when using silk cocoon. According to Table 2, total surface area of LS and SC at $5 \%(\mathrm{~V} / \mathrm{V})$ could be calculated and they were 70.43 and $558.14 \mathrm{~m}^{2}$, respectively. The cell immobilization of LS and SC was 0.080 and $0.031 \mathrm{mg} / \mathrm{g} \mathrm{BM}$, respectively. This result showed that loofa sponge had lower total surface area but higher cell immobilization and hydrogen production yield. The higher cell immobilization may cause from larger pore diameter of loofa sponge $\left(25.290{ }^{\circ} \mathrm{A}\right)$. (Pore diameter of cocoon was 18.710 $\left.{ }^{\circ} \mathrm{A}\right)$. The higher porosity spaced void for growth of microorganisms was reported by previous study ${ }^{[30]}$. Thereby, microbes possibly preferred growing on loofa sponge which gave higher hydrogen production and rate. In addition, high surface area may not result to high cell immobilization and hydrogen production, if there was low void space for the growth of microorganisms. Thus, the surface area, pore diameter and cell immobilization should be considered together. Consequently, BM from plant (loofa sponge) was able to improve hydrogen production than BM from animal (silk cocoon). 
Table 4 Hydrogen and VFA production at various loofa sponge (LS) and silk cocoon (SC) concentrations

\begin{tabular}{lllll}
\hline \multirow{2}{*}{$\begin{array}{l}\text { LS } \\
(\%)\end{array}$} & Concentration & $\mathrm{H}_{2}$ yield & \multicolumn{3}{c}{$\mathrm{VFA}(\mathrm{ppm})$} \\
\cline { 3 - 5 }$\left(\mathrm{mL} \mathrm{H}_{2} / \mathrm{g} \mathrm{COD}\right)$ & $\mathrm{HAc}^{\mathrm{a}}$ & $\mathrm{HPr}^{\mathrm{b}}$ & $\mathrm{HBu}^{\mathrm{c}}$ \\
\hline 0 & 11.64 & 51.34 & 28.00 & 171.46 \\
5 & 28.43 & 63.61 & 35.62 & 301.30 \\
10 & 21.22 & 44.93 & 35.40 & 175.95 \\
15 & 11.08 & 88.57 & 52.20 & 334.55 \\
20 & 9.66 & 103.62 & 42.73 & 293.96 \\
\hline SC Concentration & $\mathrm{H}_{2}$ yield & & $\mathrm{VFA}^{\mathrm{b}}(\mathrm{ppm})$ & \\
\cline { 3 - 5 }$(\%)$ & $\left(\mathrm{mL} \mathrm{H}_{2} / \mathrm{g}\right.$ COD $)$ & $\mathrm{HAc}^{\mathrm{a}}$ & $\mathrm{HPr}^{\mathrm{b}}$ & $\mathrm{HBu}^{\mathrm{c}}$ \\
\hline 0 & 20.12 & 8.76 & 12.93 & 48.09 \\
5 & 24.26 & 12.87 & 17.74 & 67.26 \\
10 & 17.94 & 26.09 & 36.85 & 116.14 \\
15 & 7.50 & 38.93 & 55.42 & 143.67 \\
20 & 5.18 & 67.55 & 93.98 & 198.79 \\
\hline
\end{tabular}

${ }^{\mathrm{a}} \mathrm{HAc}=$ acetic acid $;{ }^{b} \mathrm{HPr}=$ propionic acid; ${ }^{\mathrm{c}} \mathrm{HBu}=$ butyric acid

\section{Cell morphology and microbial population}

Resulting from Ribosomal Database Project (RDP) Na,e Bayesian Classifier v.2.2 with a corpus of 23,095 rRNA sequences assigned (NCBI), it was found that under optimal fermentation condition, dominant species was in Firmicutes phylum, Bacilli class, Bacillales order, Bacillaceae family, Bacillus cereus (B. cereus) with population around $47 \%$ of the mixed culture (Similarity was $97 \%$ )(Figure 1). B. cereus is gram-positve, facultatively anaerobic, spore-formimg, and rod-shape microbes ${ }^{[31]}$. Zhang et al (2014) reported that B. cereus is a hydrogen producer which efficiently using substrate such as starch and starch wastewater to produce hydrogen ${ }^{[32]}$. Results of SEM image are illustrated as in Figure 2 (Top row is LS and bottom row is SC). Microorganisms that found on surface of the BM were mostly rod shape which confirmed the bioinformatics results. Moreover, fluorescence images (Figure 3) also confirmed observation of the same shape and range size of microbes. Most of cells showed violet color which meant those cells both detected using universal and pB196 probe which targeted all microorganisms and specified only Firmicutes phylum, respectively. Lower intensity of detected was possibly because of low RNA content in the cell. Metabolically less active or inactive cells may contain low RNA content than the active one since they are in the rest state or lowering their reproduction $33-35^{\circ} \mathrm{C}$.

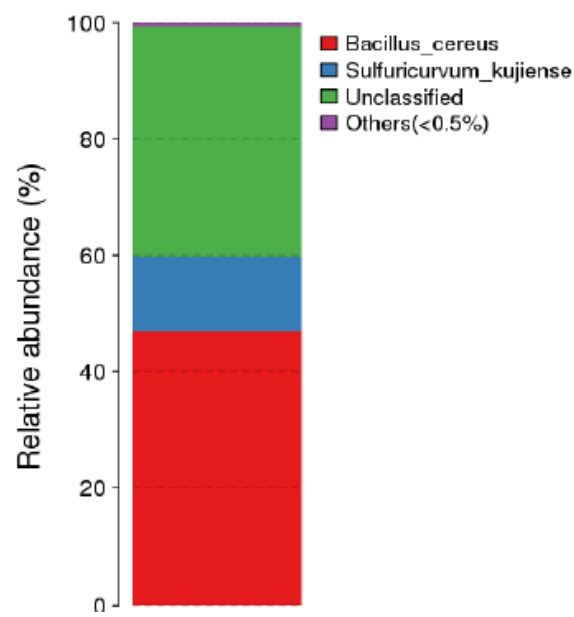

Figure 1 The taxonomic composition distribution in samples of species-level 


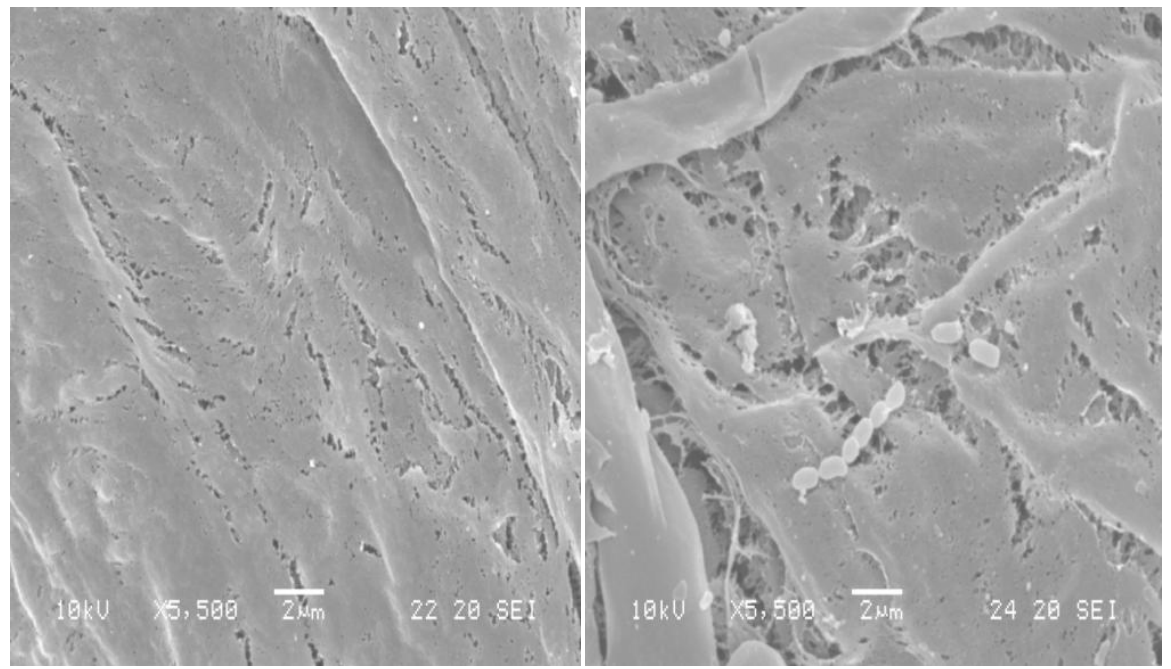

(A) loofa sponge (LS)

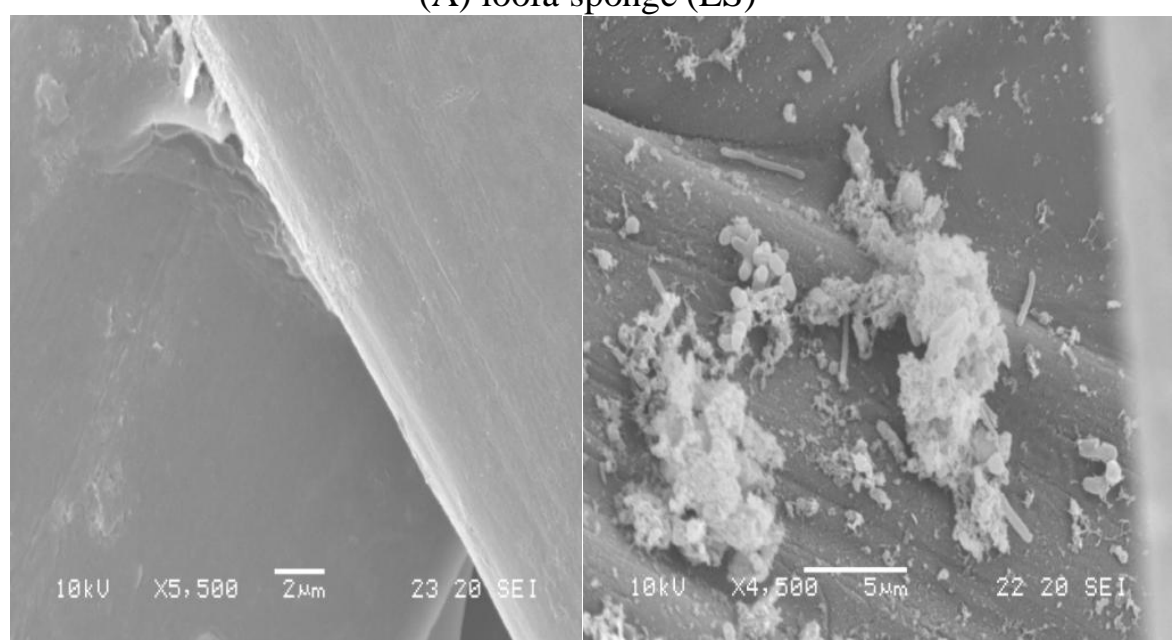

(B) silk cocoon (SC)

Figure 2 SEM images of bacterial morphologies on (A) loofa sponge (LS) and (B) silk cocoon (SC) before (left) and after (right) the fermentation

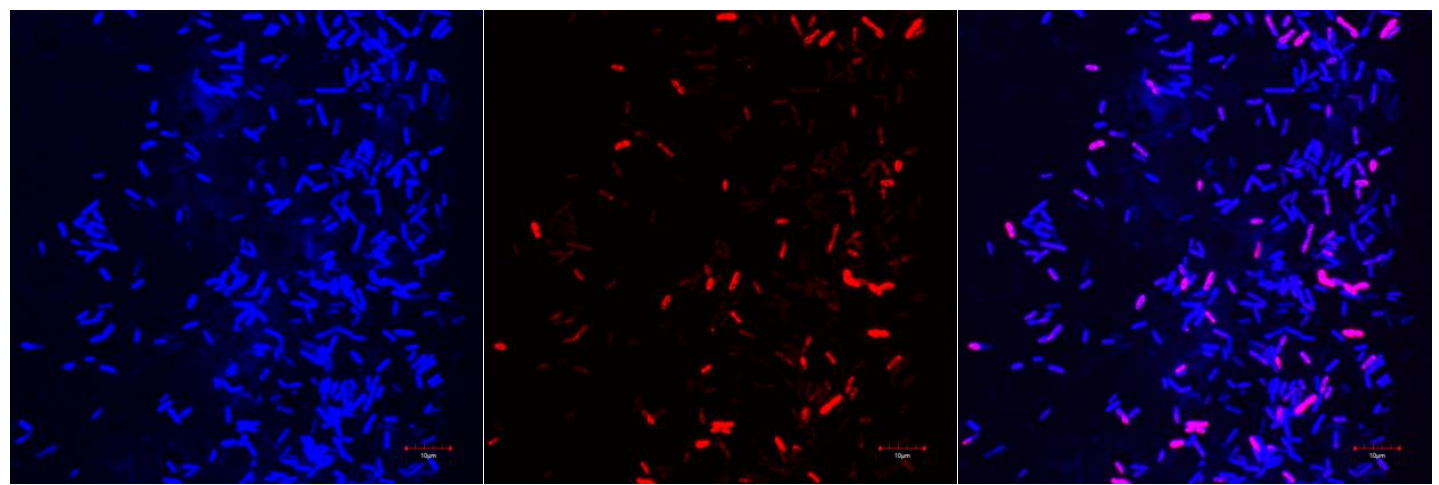

(A) Control 


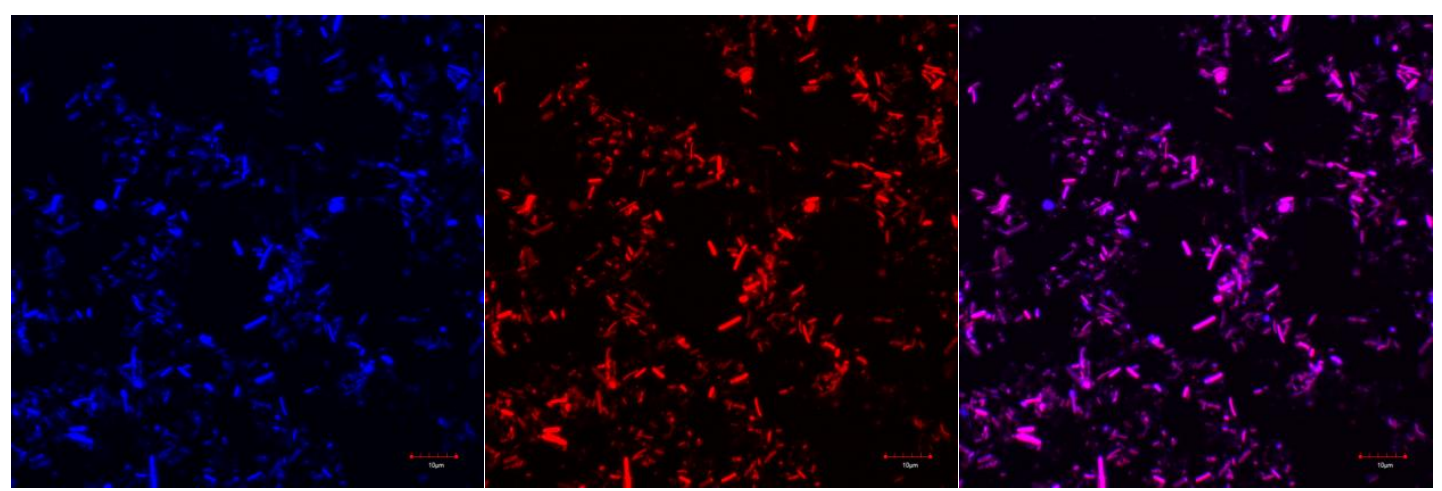

(B) LF 5\% (v/v)

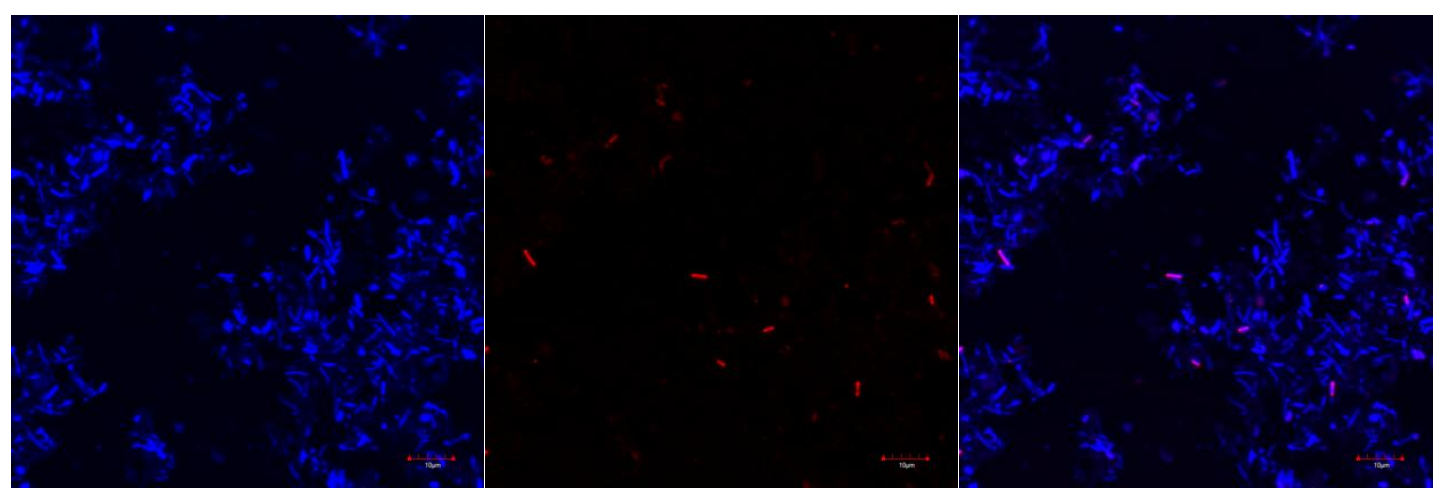

(C) SC 5\% (v/v)

Figure 3 Fluorescence images (magnified 120X) of (A) pure Bacillus (positive control) and (B)-(C) microorganisms from the surface of various BM

\section{CONCLUSIONS}

An optimal fermentation condition that obtain highest yield for biohydrogen production from starch processing wastewater in this study was initial $\mathrm{pH}$ 7.0, thermophilic temperature range, and initial iron concentration $800 \mathrm{mg} \mathrm{Fe} / \mathrm{L}$. However, optimal operational value should be consider under circumstances because different parameters, for example source of substrate, source of microbial seed, dominant species in the cultures and so on, may prefer dissimilar environmental conditions. Besides too high iron concentration would harm the microbes and lower the hydrogen production.

Furthermore, cell immobilization by addition of biomaterials (BM) could improve hydrogen yield by 2 folded comparing to the non-addition. BM from plants (loofa sponge) was found producing higher yield than that from animals (silk cocoon), and optimal concentration of $\mathrm{BM}$ was $5 \%(\mathrm{~V} / \mathrm{V})$. Decreasing of hydrogen yield observed when increasing $\mathrm{BM}$ concentration since too high $\mathrm{BM}$ concentration may lower space for microbial growth and limit the circulation of the fermentation liquid. On $\mathrm{BM}$ from the optimal concentration and fermentation condition, it was mostly found rod-shaped, size range of 1-5 $\mu \mathrm{m}$, Firmicutes phylum, Bacillus cereus with population of $47 \%$ of all specie detected. This specie was also reported as efficient starch-utilizing hydrogen producers. 


\section{ACKNOWLEDGMENTS}

The authors gratefully acknowledged to National Research Council of Thailand and Faculty of Environment and Resource Studies of Mahidol University Alumni Association, Thailand for financial support of this research. We also express our greatest thanks to Associate Professor Dr. Chumlong Arunlertaree and Associate Professor Dr. Benjaphorn Prapagdee of Mahidol University, Thailand for their helpful suggestions.

\section{REFERENCES}

1-Wongthanate $\mathrm{J}$, Chinnacotpong $\mathrm{K}$, Khumpong $\mathrm{M}$. Impacts of $\mathrm{pH}$, temperature, and pretreatment method on biohydrogen from organic waste by sewage microflora. Int $J$ Energy Environ Eng. 2014; 5: 1-6.

2-Show KY, Lee DJ, Chang JS. Bioreactor and process design for biohydrogen production. Bioresour Technol. 2011; 102: 8524-8533.

3-2- Li CL, Fang HHP. Fermentative hydrogen production from wastewater and solid wastes by mixed cultures. Crit Rev Env Sci Technol. 2007; 37: 1-39.

4-Cheng JS, Yin DM, Li SY, Yuan YJ. Activation of ERK-like MAP Kinase Involved in Regulating the Cellular Proliferation and Differentiation of Immobilized Taxus cuspidata Cells. Enzyme Microb Technol. 2006; 39: 1250-1257.

5-Wu SY, Lin CN, Chang JS. Hydrogen Production with Immobilized Sewage Sludge in Three-Phase Fluidized-Bed Bioreactors. Biotechnol Prog. 2003; 19: 828-832.

6-American Public Health Association (APHA). Standard methods for the examination of water and wastewater. $22^{\text {nd }}$ ed. Washington D.C.; 2012.

7-Lin CY, Chang RC. Fermentative Hydrogen Production at Ambient Temperature. Int J Hydrogen Energy. 2004; 29 (7): 715 - 720.

8-Selembo PA, Merrill MD, Logan BE. The use of stainless steel and nickel alloys as lowcost cathodes in microbial electrolysis cells. J Power Sources. 2009; 190: 271 - 278.

9-Owen WF, Stuckey DC, Healy JJB, Young LY, McCarty PL. Bioassay for monitoring biochemical methane potential and anaerobic toxicity. Water Res. 1979; 13 (6): 485-492.

10-Wongthanate J, Polprasert C. Immobilized biofilm in thermophilic biohydrogen production using synthetic versus biological materials. Braz Arch Biol Technol. 2015; 58 (1): 123-129.

11-Zampieri A, Mabande GTP, Selvam T, Schwieger W, Rudolph A, Hermann R, Sieber $\mathrm{H}$, Greil P. Biotemplating of Luffa cylindrica sponges to self-supporting hierarchical zeolite macrostructures for bio-inspired structured catalytic reactors. Mater Sci Eng C. 2006; 26: 130-135.

12- Chu CF, Ebie Y, Inamori Y, Kong H. Effect of Hydraulic Retention Time on the Hydrogen Yield and Population of Clostridium in Hydrogen Fermentation of Glucose. $J$ Environ Sci. 2009; 21: 424-428.

13- Mizrahi-Man O, Davenport ER, Gilad Y. Taxonomic Classification of Bacterial 16S rRNA Genes Using Short Sequencing Reads: Evaluation of Effective Study Designs. PLoS ONE. 2013; 8(1): e53608.

14- Edgar, R.C. UPARSE: Highly accurate OTU sequences from microbial amplicon reads. Nat Methods. 2013; 10(10): 996-998.

15- Wang Q, Garrity GM, Tiedje JM, Cole JR. Naïve Bayesian classifier for rapid assignment of rRNA sequences into the new bacterial taxonomy. Appl Environ Microbiol. 2007; 73(16): 5261-5267.

16- Meier H, Amann R, Ludwig W, Schleifer KH. Specific Oligonucleotide Probes for in situ Detection of a Major Group of Gram-positive Bacteria with low DNA G+C Content. Syst Appl Microbiol. 1999; 22 (2): 186-196.

17-Sivaramakrishna D, Sreekanth D, Sivaramakrishnan M, Kumar BS, Himabindu V, Narasu ML. Effect of system optimizing conditions on biohydrogen production from herbal wastewater by slaughterhouse sludge. Int J Hydrogen Energy. 2014; 39: 75267533. 
18- Hawkes FR, Dinsdale R, Hawkes DL, Hussy I. Sustainable fermentative hydrogen production: challenges for process optimization. Int J Hydrogen Energy. 2002; 27: 1339 1347.

19- Ghimire A, Frunzo L, Pirozzi F, Trably E, Escudie R, Lens PNL, Esposito G. A review on dark fermentative biohydrogen production from organic biomass: Process parameters and use of by-products. Appl Energy. 2015; 144: 73-95.

20- Kim SH, Han SK, Shin SH. Effect of substrate concentration on hydrogen production and $16 \mathrm{~S}$ rDNA-based analysis of the microbial community in a continuous fermenter. Process Biochem. 2006; 41: 199-207.

21- Ntaikou I, Antonopoulou G, Lyberatos G. Biohydrogen Production from Biomass and Wastes via Dark Fermentation: A Review. Waste Biomass Valori. 2010; 1: 21-39.

22- Lee HS. Biological hydrogen production from biomass using dark fermentation and microbial electrolysis cell, ProQuest: Michigan; 2009, pp.35.

23- Khanna N, Kotay SM, Gilbert JJ, Das D. Improvement of biohydrogen production by Enterobacter cloacae IIT-BT 08 under regulated pH. J Biotechnol. 2011; 152: 9-15.

24-Xiao Y, Zhang Z, Minglong Z,Wensong T. Effect of the culture media optimization,pHand temperature on the biohydrogen production and the hydrogenase activities by Klebsiella pneumoniae ECU-15. Bioresour Technol. 2013; 137: 9-17.

25- Wang JL, Wan W. Factors influencing fermentative hydrogen production: A review. Int J Hydrogen Energy. 2009; 34: 799-811.

26- Wang JL, Wan W. Effect of Fe2+ concentration on fermentative hydrogen production by mixed cultures. Int J Hydrogen Energy. 2008b; 33. 1215-1220.

27-Zhang Y, Shen J. Effect of temperature and iron concentration on the growth and hydrogen production of mixed bacteria. Int J Hydrogen Energy. 2006; 31: 441-446.

28-Zhang Y, Liu G, Shen, J. Hydrogen production in batch culture of mixed bacteria with sucrose under different iron concentrations. Int J Hydrogen Energy. 2005; 30: 855-860.

29- Klebanoff L. Hydrogen Storage Technology: Materials and Applications. CRC Press: Florida; 2012, pp. 331.

30- Li WW, Yu HQ. Biohydrogen Production with High-Rate Bioreactors. In Pandey, A., Larroche, C., Ricke, S., Dussap, C.-G., Gnansounou, E. Biofuels: Alternative Feedstocks and Conversion Processes. Elsevier: 2011, pp. 544-545.

31- Bottone EJ. Bacillus cereus, a Volatile Human Pathogen. Clin Microbiol Rev. 2010; 23 : 382-398.

32- Zhang T, Bao M, Wang Y, Su H, Tan T. Genome Sequence of Bacillus cereus Strain A1, an Efficient Starch-Utilizing Producer of Hydrogen. Genome Announc. 2014; 2: 1-2. 